University of Wollongong

Research Online

Faculty of Law, Humanities and the Arts Papers (Archive)

Faculty of Arts, Social Sciences \& Humanities

$1-1-2015$

Populism and criminal justice policy: an Australian case study of nonpunitive responses to alcohol-related violence

Julia Quilter

University of Wollongong, jquilter@uow.edu.au

Follow this and additional works at: https://ro.uow.edu.au/lhapapers

Part of the Arts and Humanities Commons, and the Law Commons

Research Online is the open access institutional repository for the University of Wollongong. For further information contact the UOW Library: research-pubs@uow.edu.au 


\title{
Populism and criminal justice policy: an Australian case study of non-punitive responses to alcohol-related violence
}

\author{
Abstract \\ Populism is widely regarded in the literature as a negative and inherently punitive influence on criminal \\ justice policy. This article challenges this view and highlights the ways in which populism can produce \\ forms of citizen engagement in the criminal justice context that are new and progressive. These \\ possibilities are illustrated through a close analysis of the responses to a single instance of 'random' fatal \\ violence: the killing of Thomas Kelly in King's Cross, Sydney, in 2012. This case study shows how a \\ populist campaign powerfully realigned political allegiances to call for, and achieve, real and enduring \\ action from the New South Wales Government in addressing alcohol-related violence.

\section{Keywords} \\ violence, australian, case, related, alcohol, responses, punitive, non, study, populism, criminal, justice, \\ policy

\section{Disciplines} \\ Arts and Humanities | Law

\section{Publication Details} \\ Quilter, J. (2015). Populism and criminal justice policy: an Australian case study of non-punitive \\ responses to alcohol-related violence. Australian and New Zealand Journal of Criminology, 48 (1), p24-52.
}




\title{
Populism and criminal justice policy: An Australian case study of non-punitive responses to alcohol related violence
}

\section{Julia Quilter}

(Faculty of Law, Humanities and the Arts,) University of Wollongong, Australia

\begin{abstract}
Populism is widely regarded in the literature as a negative and inherently punitive influence on criminal justice policy. This article challenges this view and highlights the ways in which populism can produce forms of citizen engagement in the criminal justice context that are new and progressive. These possibilities are illustrated through a close analysis of the responses to a single instance of 'random' fatal violence: the killing of Thomas Kelly in King's Cross, Sydney, in 2012. This case study shows how a populist campaign powerfully realigned political allegiances to call for, and achieve, real and enduring action from the New South Wales Government in addressing alcohol related violence.
\end{abstract}

\section{Introduction}

This article is written against the well documented background of declining citizen participation in traditional and organised forms of democracy (from political parties to the trade union movement) (Stoker 2006) including in Australia (Koziol 2013; Alexander 2013) together with the general decline in trust in politicians, existing political processes, and the legitimacy of professional judgment including the judiciary and expert opinion (Pratt 2008; Allen \& Hough 2008; Stoker 2006). Against this background this article aims to explore how citizens engage politically in new and progressive ways, particularly in the criminal justice context. In doing so, I take as a starting point the most significant influence on contemporary criminal justice policy, 'penal populism'. Most scholars analysing penal populism are generally critical of it - and, given the alarming explosion in prison populations across Western countries, for good reason. Critics of penal populism focus on its emotive and rhetorical style, arguing that these should be eschewed in favour of a more rational crime policy debate (Roberts \& Stalans 1997) to be held in alternative forums away from tabloid journalism and electoral politics (Hutton 2008). A central goal is to better inform the public about criminal justice issues and a typical strategy is to criticise the media for distorting the facts and presenting stories in an unbalanced way.

Such goals and strategies may well be worthy ones, however, against this grain, I am interested to explore how 'populism' might be constructively engaged rather than banished, and decoupled from its punitive 'penal' partner (Hogg 2013). In doing so, to be clear, my own normative position is opposed to the punitive 'law and order' responses generated by penal populism and to the conservative right-wing agendas of recent populist movements such as Pauline Hanson's One Nation Party in Australia or the Tea Party in the US. That said, by drawing on the work of scholars 
such as Canovan (1981, 1995, 2005), Kazin (1998) and Laclau (2007), my argument is that populism does not have a pre-ordained ideological content but may be viewed as a set of tools that can be put to use in a systematic way. In particular, I am interested in the potentially progressive and non-punitive role the emotions, rhetoric and the media may play in a populist campaign in order to influence criminal justice policy. I analyse these issues through a close reading of the responses to the death of Thomas Kelly, in Sydney, Australia in July 2012. Mr Kelly's tragic death resonated with the community at large triggering a powerful populist campaign of a very different non-punitive nature. Mr Kelly became a 'popular identity' unifying a series of otherwise differential claims (Laclau 2007), voices, interests and organisations and powerfully realigning political allegiances - notably those of the Police with emergency service workers and away from 'law and order' politics - in a campaign directed at alcohol-related violence. Through 'Thomas Kelly' this campaign called for (and obtained) real and enduring action from the New South Wales (NSW) Government. My rationale for a case study examination of a specific local campaign is that much can be learned about populism's potential to inform constructive policymaking from a close examination of the dynamics, nuance and specificity of a particular campaign, and that the insights that are made possible from a close reading of this instance have wider relevance and application.

This article is in three parts. The first discusses penal populism and its critiques before turning to the structural features of populist movements generally. The second part of the article turns to the Thomas Kelly case study and provides an overview of the Government's responses to his death. The final part of the article, explores the populist campaign that underpinned the 'call to action' to the Government.

\section{Penal populism and populism}

While the social, economic and cultural conditions of possibility of penal populism are beyond the scope of this article (eg. Garland 2000, 2001; Pratt 2007, 2008; Roberts et al 2003; Dzur 2010), it is arguably the most significant influence on contemporary criminal justice policy in modern society (Pratt 2007; cf Pratt \& Eriksson 2013). It is 'intended to convey the notion of politicians tapping into and using for their own purposes, what they believe to be the public's generally punitive stance' (Bottoms 1995, p. 40). As such, penal populism is most commonly associated with the trend in many western countries (US, UK, NZ and Australia) since the 1980s towards punitive and populist penal policies and sentencing laws (Garland 2001; Pratt 2006; Lacey 2008; Roberts et al 2003). Penal populism equates effective punishment with severity and particularly in the form of incarceration (Dzur 2012; Pratt 2007). The overwhelming significance of this policy approach is evidenced by the significant expansion of the prison population across many Western countries since the 1990 s - and this, ironically and sadly, precisely at a time when crime rates are falling across those same countries (Pratt 2007; Pratt \& Eriksson 2013; cf Matthews 2005). 
If exploding prison populations are the most worrying outcome of penal populism, 'law and order' legislative responses are their predominant cause (Hogg \& Brown 1998). A typical way such 'law and order' responses arise is after a specific event generating community or popular outrage occurs (Loughnan 2009; Roberts et al 2003) the government responds by introducing (often poorly crafted) new criminal offences or increased penalties. There have been numerous examples of such 'knee-jerk' reactions in the Australian state of NSW. A recent illustration is the Government's response to a series of drive by shootings by introducing new offences (e.g. firing a fire arm at a dwelling) and new consorting laws in the Crimes Amendment (Consorting and Organised Crime) Act 2012. (For other examples see Loughnan 2009; Brown 2013).

Another manifestation of penal populism is that in response to alleged leniency in sentencing and parole determinations, governments have introduced various forms of legislation that attempt to fetter judicial discretion and prolong custodial or supervisory orders (Roberts et al 2003). Some examples include: 'three strikes legislation'; mandatory and minimum sentencing; standard non-parole periods; serious sex offender restraining orders and notification and registration schemes; and continuing detention orders. Increasing imprisonment rates and 'law and order' responses such as these are the primary responses offered by penal populism. (See also Roberts et al 2003; Freiberg 2008.) As will be discussed further below, these simplistic political responses fail to deliver what the public expect, including preventing crime.

These trends reflect the punitive aspect of penal populism, which is to be lamented, but the latter term in the phrase - populism - captures an important constitutive change in the relations between politicians and publics (Pratt 2007; Roberts 2008; Roberts \& Stalans 1997; Hogg 2013). Since the 1980s the close relationship between governments and public servants (such as corrections departments and penal reform groups) and other related criminal justice professionals in the establishment of penal policy has been eroded (Pratt 2007, 2008; Roberts 2008; Loader 2006). Where once, the public were largely bystanders in relation to criminal justice policy, today politicians, particularly through focus groups, are keen to track voter sentiment and align themselves and their policies with such public opinion. This re-configured relationship has been accentuated by the 24 hour news cycle, and the rise of the victims' movement (Freiberg \& Gelb 2008; Roberts 2008; Pratt 2007; Hogg 2013). As Pratt has said (2007, p. 32):

Penal populism revolves around the idea that the public are not mere dummies but can and should have a significant influence on penal affairs government's not only just listen to them but are also keen to strike up alliances with them or even be led by them. 
Other examples of this reconfigured relationship include the consultative role accorded to the public in sentencing commissions in the US and in some Sentencing Advisory Councils in Australia (Freiberg \& Gelb 2008).

In addition to centring the public, penal populism operates through a highly rhetorical and emotive style. This contrasts strongly with the previous more rational, formal and administrative processes of criminal justice officials and experts (Dzur 2012; Garland 2000,2001 ) who also, unlike the current climate of politicising crime, aimed to keep crime and criminal justice policy out of the political realm (Garland 2000; Loader 2006; Newburn 2007). The language of penal populism is characterised by its 'commonsensical anti-intellectual' style (Pratt 2007, p. 17). For example, laws named specifically after victims (Megan's law, Sarah's law, Zoe's law) or popular slogans 'three strikes legislation' or 'serious sex offender legislation'. The language not only embeds the 'public' (particularly victims) but its emotive rhetoric plays to the sentiment of the broader public.

\section{'Remedies' to penal populism}

Primarily because of its association with rising prison populations, penal populism has attracted significant criticisms (eg. Pratt 2007; Roberts et al 2003; Lacey 2008). A recurring theme in critiques is the suggestion that the solution is to foster a more informed public, through greater public education in an attempt to make the public less punitive. Studies for instance, demonstrate that the methodology used to survey the public affects the results - and while this is true generally of all surveying it is specifically so in relation to surveys on crime and punishment. For instance, using deliberative polling techniques or conducting attitude change research, demonstrates that the public are less punitive in their responses to punishment and more inclined towards rehabilitation and other alternatives to incarceration when they are given more information and can debate policy issues (eg Hutton 2005, 2008; Roberts and Hough 2002; Cullen, Fisher and Applegate 2000). Furthermore, studies evidence that public opinion is not stable or monolithic but is more 'contradictory, nuanced and fragile - that there is support both for punitiveness but also more constructive community based solutions' (Hutton 2005, p. 254). As such it is argued that greater public education and consultation can change punitive attitudes and, as will be discussed below, will lead to more rational penal policy.

Leading on from this, many critics of penal populism argue that penal policy should eschew popular emotionalism and replace it with a more rational crime policy based on reliable (usually statistical) information (Roberts 2008; Pratt 2008; Hutton 2008). This would have the effect of overcoming current distorted political and media communications. For example, Roberts and Stalans (1997, pp. 291 and 294) argue, it is:

Incumbent upon the criminal justice system to strive to educate the public to a greater degree than at present. (emphasis added) 
...the public can only be expected to rationally participate in the debate over criminal justice policy when they have an accurate idea of the extent of the problem, and the relative effectiveness (and costs) of various solutions. (see also Hutton 2008)

These sentiments are echoed in Roberts, Stalans, Indermaur and Hough's later five country study of Australia, New Zealand, Canada, US and UK (Roberts et al 2003), where the authors argue that penal populism involves the exploitation of misinformed opinion in the pursuit of electoral advantage. It is argued that '[i]nformed opinion' of both politicians and the public (p. 161) is the answer (see also Roberts \& Stalans 1997). A properly informed public, it is argued, will lead to a more rational debate based on evidence, replacing the current emotionalism (Roberts et al 2003, p. 14). As Hutton claims (2008, pp. 212-3):

...The political challenge is to find a means of involving the public in penal policy-making in a forum that creates space for rational debate away from the harsh spotlight of tabloid journalism and electoral politics.

The two chief so-called weaknesses of penal populism, the uninformed nature of the public and the emotive aspect, it is argued, should be fixed with 'accurate' information and by casting out the emotive as irrelevant. It is not per se concerned with the centring of the public; rather it is the public's 'uninformed' nature that is the problem. The media is a typical target with calls for it to stop distorting the 'facts' and to provide information to the public in a more balanced way (Roberts in Freiberg \& Gelb, p. 27).

While these goals may well be important, as Hogg has argued, they nevertheless seem to evade rather than engage with the realities of contemporary penal politics (2013, p. 109) - and not least the important role that the media and new social media technologies now play in such debates. Like Hogg (2013), it is also unclear to me whether a more rational, informed policy approach will occupy anything other than a secondary role. Indeed, this seems to be conceded by Roberts et al (2003, p. 164):

It is now clear that against the emotional and dramatic appeal of populist crime policy, 'rational' information-based and 'criminological' perspectives are often considered irrelevant. People are not satisfied by what appears to be cold rationalism.

As will be discussed below, I take issue with these suggested 'remedies', instead exploring the progressive possibilities of populism including its style - how it can be harnessed for different ends. As Garland $(2000,2001)$ and others (Hutton 2005) have recognised, attitudes to crime are culturally produced and include complex emotional and symbolic elements; they are not simply about 'the facts' or about 'accurate information' (Garland 2000, p. 364): 
Our attitudes to crime - our fears and resentments, but also our common sense narratives and understandings - become settled cultural facts that are sustained and reproduced by cultural scripts and not by criminological research or official data. (Garland 2000, p. 368)

The provision of greater information to the public (and politicians) in a 'rational' way will not simply fix the problem (Hutton 2005, p. 253), since attitudes to crime and punishment reflect, at least in part, broader anxieties and insecurities, and are thus not directly connected to accurate information about crime and punishment (Hutton 2005, pp. 253-4). To that end, we know statistically that crime has been declining during the very period (from the mid-1990s) in which penal populist policies has taken hold. This is a known statistical fact but has done little to curb punitive policies.

It is also important to recognise that dispassionate, statistical, rational debate is often less than compelling or meaningful to human agents (Freiberg 2001, p. 266). It is necessary, as I will discuss further below, to engage with the emotional and symbolic elements of crime. Freiberg (2001) has made a similar point arguing that 'rational' crime policy is insufficient - crime policy must tap the deeper psycho-social forces which have driven penal populism (p. 266) which the 'dispassionate/scientific' manner fails to capture or address. He argues that while uncertainty, instability and complexity may have fuelled the punitive aspect of current criminal justice policies, people have positive feelings about harmony, order, predictability and stability. (See also Pratt 2008; Loader 2006; Garland 2000.) Crime policies should tap these emotions and enact social conditions that foster them, particularly social cohesion:

Sentencing is as much about politics as it is about law or criminology. It is as much about the emotional, affective and symbolic elements of crime, order and safety as it is about the rational, effective and instrumental aspects of law-making, judging and the disposition of offenders. (Freiberg 2008, p. 148)

Other solutions to the rise of penal populism are argued to be the establishment of independent bodies (such as sentencing councils or penal policy boards) and improving confidence in professionals and experts (Lacey 2008; Pratt 2008; see also Dzur 2010). These solutions have been suggested based on studies of countries that have 'escaped' the punitive aspect of penal populism such as the Nordic countries studied by Pratt and Eriksson (2013). Such countries have higher levels of respect for professionals and utilise independent bodies for setting criminal justice policy. My concern with these solutions, as I will discuss in the next part of this article, is that this fails to recognise the important role that the public can and have played historically in populist movements (Dzur 2010, 2012) and it elides the contemporary political landscape in which the public has assumed a significant role in criminal justice policy formation: it seems to me that it is simply too late to go back to the safety of professional experts - as appealing as that may be for an academic! 
As the name suggests, penal populism may be viewed as a form of populism (or perhaps more appropriately what Taggart calls 'new populism' (2000)). What populist movements all have in common, is a claim to represent 'the people'. My argument is that penal populism fails the people not because it centres the public (for how could that be a failing) nor because of its emotional and rhetorical style, but because it rarely produces the effects it allegedly aims to. We know that increasing incarceration rates does not lead to reductions in crime nor is there any evidence that it leads to a stronger sense of safety. By defining complex social problems as 'law and order' issues and by operating primarily through blunt legislative instruments (such as the creation of new offences) or increasing police powers and resources, penal populism fails to respond adequately to the complexity of the issues involved. In the next section, by looking more closely at the structural features of populism (including its focus on the people and its rhetorical and emotional style), I am interested in the possibilities of harnessing its positive potential for criminal justice debates (Hogg 2013). I want to explore the potential for a genuinely populist response which is multi-faceted and nuanced - an approach which includes mechanisms within and outside criminal law and policing.

\section{Populism}

While many today associate populism with conservative right-wing movements like Pauline Hanson's One Nation Party or the Tea Party in the US, populism has been utilised by all sides of the political spectrum. As documented by Canovan (1981) and others, populism historically was associated with a series of progressive movements - whether those of agrarian populism (farmer's radicalism such as the US People's Party; the peasant movements in the East European Green Rising; intellectual agrarian socialism in the narodniki) or political populisms (such as populist democracies calling for referendums and 'participation'). Kazin's (1998) historical study from the $19^{\text {th }}$ century roots of populism in the US through to today, also powerfully charts that it was only from the late 1940s that populism began its migration from Left to Right wing and only from the 1960s did conservatives begin to grasp its electoral potential (Kazin 1998, p. 5).

What this demonstrates is, as Laclau has argued (2007, p.176):

Populism is not a fixed constellation but a series of discursive resources which can be put to very different uses. It is thus a set of resources available to a plurality of actors, in a more or less systematic way. (emphasis added)

In other words, populism does not have a pre-ordained ideological content but may be viewed as a set of tools that can be put to use in a systematic way. As such, attempts at defining populism on an 'ideological' basis have failed (Laclau 2007).

While attempts at definitional precision based on ideology may fail, it is possible to outline some of its broad features (see also Hogg 2013). What all populist movements (including penal populism) have in common is at heart a claim to 
represent 'the people'. While who 'the people' are, is a complicated and often contested question, it is also a mark of 'its political usefulness; captured at different times by many different political causes, it has been stretched to fit their different shapes.' (Canovan 2005, p. 3) As Canovan has discussed, 'the people' encompasses the 'whole political community' but also some smaller often excluded group, the common or ordinary person (Canovan 2005, p. 90).

While the appeal to the notion of 'the people' is clearly an important rhetorical source of legitimacy for populist causes, my own interest is in harnessing the possible constructive participatory element that this may provide. At a point when formal democratic participation (including membership of trade unions and political parties) is at all-time lows including in Australia (Stoker 2006; Koziol 2013; Alexander 2013), it seems crucial to develop a civic capacity, a sense of 'public work'. Dzur speaks of this as 'thick populism' - a sense of ownership and public responsibility for public work and policy making (Dzur 2010, 2012).

The style of populism is reflective of its claim to represent the people, it being characterised by simple direct language - a distrust of jargon and experts - and a willingness to communicate in a tabloid way (Canovan 1981, 1999; Kazin 1998). This enables a reduction of the complexity of the issues presented to the people something that has become characteristic of contemporary politics generally (Arditi 2007, p. 62).

Canovan has described the mood of populism as having a revivalist flavour, powered by the enthusiasm that draws normally un-political people into the political arena. It plays to the emotions which are often heightened by populist movements being led by a charismatic leader (Canovan 2005, p. 89). The centrality of a leader (symbol or identity) for most populist movements will be discussed further below. Populism is described as having an episodic character which means it can often be short-lived (Taggart 2000, p. 5; Canovan 2005, p. 89). It has also been described as having an antagonistic, insurgent method emerging at times of crisis (Taggart 2000; Hogg 2013). As an antagonistic force, populism, therefore, has the capacity to disturb and renew the political process (Arditi 2007, p. 52) - it functions within democracy but can also endanger its framework (Arditi 2007). As discussed above, my interest is on how it may be a force for renewing the political.

Many of these general features of populism are elaborated in the work of Ernesto Laclau (Laclau 2007). ${ }^{1}$ Laclau's work, while dense, is useful as he attributes a number of structural features to any populist rationality. I will focus on four here which I will then use in relation to analysing the Thomas Kelly case study.

If a populist movement is to emerge, Laclau argues that first an 'internal antagonistic frontier' must be formed dividing society into two camps - separating the 'people' from power. In doing so, populism 'simplifies' the political space, replacing a complex set of differences by a stark dichotomy whose two poles are necessarily imprecise 
(Laclau 2007, p. 18). This simplification of the political landscape allows for a binary to be established, in traditional political terms, between 'the people' and the (misguided or corrupt) elites but more commonly today, between 'us' and 'them'.

Secondly, there must be a unification of a plurality of demands in what Laclau calls an equivalential chain. For Laclau the smallest unit of analysis is the 'social demand' - meaning, in English, both request and claim. When a demand in the sense of a request is not satisfied it becomes a claim and may be put together with other unsatisfied demands (eg an initial request for better wages when unsatisfied may be put together with other such demands such as problems with water, health, schooling and so on). If the situation remains unchanged there is an accumulation of unfulfilled demands and an increasing inability of the institutional system to absorb them in a differential way (ie in isolation from the others) and this is when Laclau says, an equivalential relation is established between them. Importantly, when they form an equivalential chain they may begin to constitute a broader social subjectivity that Laclau calls popular demands - they begin to constitute the 'people' as a potential historical actor (Laclau 2007, p. 74) and as the ultimate source of political authority.

Thirdly, the equivalential chain must be consolidated through the construction of a popular identity which is something more than the simple sum of the equivalential links. The popular identity is usually one of the individual demands from the equivalential links which comes to embody the totality of the series - it operates through a synedochal structure. This demand remains a particular demand yet it also becomes the signifier of a wider universality embracing all of the heterogenous demands. Laclau argues that the popular identity (whether word or image) is, however, an empty signifier - it can now name a much greater universality - and this popular symbol or identity actively constitutes the unity rather than passively expressing a previously given one. For example, the words 'justice' or 'freedom' have an undifferentiated fullness - they are not abstract terms but in the strictest sense are empty and can be invested with a multiplicity of demands. Importantly, grievances which have nothing to do with such demands can nevertheless be expressed through them.

Finally, populism works on the affective/emotional realm and this is often found most troubling about populism (and penal populism, as discussed above): that it operates on the emotions, through suggestibility and in and on the 'crowd'. Instead of starting with a model of political rationality which sees populism in terms of what it lacks vagueness, anti-intellectualism, pure rhetoric - Laclau, drawing on the work of poststructuralists who have argued that there is no fixed meaning between a signifier and signified, sees vagueness, imprecision and rhetoric as preconditions to constructing relevant political meanings.

In the next two parts to this article, I want to explore the structure of populism within the context of a case study into the responses to the death of Thomas Kelly. These 
responses constitute a populist event in Laclau's terms, and it illustrates that populism in a criminal justice context need not have a solely or primarily punitive nature. This case study is informed by a reading and analysis of key texts: media stories relating to Thomas Kelly for the period from Thomas Kelly's death to September 2013 searched via Factiva which includes coverage of all major tabloid and broadsheets in Australia; Hansard speeches and debates; legislation enacted; relevant Ministerial Press Releases and other related documents; City of Sydney management plans and Lord Mayor Press Releases; and analysis of the documents of related organisations (such as the Australian Medical Association (AMA), the Coalition of Concerned Emergency Services Workers, Foundation for Alcohol Research Education (FARE) and the Police Association).

\section{Responses to the death of Thomas Kelly}

Just after 10pm on Saturday, 7 July 2012, Thomas Kelly, 18 years of age, alighted from a taxi to begin his first night out in Kings $\mathrm{Cross}^{2}$, Sydney, with his girlfriend. Some minutes later when they were walking down Victoria Street, in an unprovoked attack, Thomas was king-hit ${ }^{3}$ in the face as he talked on his mobile phone near the Mercure Hotel, not far from the iconic 'Coke' sign in the place locals refer to as 'the Cross'. He fell to the ground, hitting his head on the footpath, resulting in serious head injuries. He was transported by ambulance to St Vincent's Hospital, Darlinghurst, where he received medical attention but never regained consciousness. On Monday evening, 9 July 2012, his family made the heartwrenching decision to terminate his life support - they did so in time for Thomas' organs to be donated to others. (SMH, 11 July 2012)

On Wednesday, 18 July 2012, at approximately 7.30pm Homicide Detectives arrested Kieran Loveridge, 18 years of age, of Seven Hills in Western Sydney, and just before midnight charged him with the murder of Thomas Kelly. He was ultimately also charged with four other assaults from unrelated events on Saturday, 7 July 2012. Almost a year later, on 18 June 2013, Mr Loveridge pleaded guilty to the manslaughter of Mr Kelly and the four other assaults that occurred on the same evening he king-hit Mr Kelly. On 8 November 2013, Justice Campbell sentenced Mr Loveridge to a total of 7 years and 2 months for the combined manslaughter and four assaults being, 6 years for manslaughter ( 4 years non-parole period) and 1 year and 2 months for the assaults - with an effective non-parole period of 5 years and 2 months. The first date he will be eligible for parole is 18 November $2017(R v$ Loveridge [2013] NSWSC 1638, [79]-[80]). ${ }^{4}$

As a result of the sentencing proceedings, we now know more about the facts of the evening and particularly regarding Mr Loveridge's alcohol affected state. From the agreed statement of facts tendered in the proceedings, the judgment (Loveridge at [9]) indicates that Mr Loveridge began drinking with two (or three) friends at around 
$5 \mathrm{pm}$ and by 7:30pm they had consumed between them a carton of two-doxen mixed drinks, each having an equivalent to 1.9 standard drinks. By this time, they had arrived in Darling Harbour by car where they went to a bar and drank further mixed drinks. They then caught a taxi to Kings Cross where they went to a bar in Darlinghurst Road shortly before 9pm. Justice Campbell found, '[d]espite the lack of precision in the evidence, I am satisfied beyond reasonable doubt that by 9:30pm on 7th July 2012, the offender was very drunk.' (Loveridge at [11]) Shortly afterwards the first assault occasioning actual bodily harm was committed and thereafter the fatal blow to Mr Kelly was struck. (The three other assaults occurred afterwards: Loveridge at [19].)

As will be discussed below, it is significant given that the populist campaign from its outset focused on alcohol-related violence, that at the time of the events in July 2012 and, as far as this author is aware, until the agreed statement of facts was tendered in the sentencing proceedings in September 2013, that information about $\mathrm{Mr}$ Loveridge's drunken state was not made 'public's - either via the media, Police, governmental or other discourses. In July 2012 when Mr Kelly was killed until the sentencing proceedings, whether or not Mr Loveridge was affected by drugs (such as methamphetamines) or alcohol or a combination of both was unknown (eg see Telegraph, 12 July 2012; SMH, 14 July 2012; Sun-Herald, 15 July 2012). Furthermore, prior to the sentencing hearing very little attention was paid to $\mathrm{Mr}$ Loveridge in the media. There was no reporting on his background, criminal record and the fact that he was on conditional liberty at the time of committing the offence. Arguably, this was because legal proceedings were on-foot but this was also significant because, as will be discussed below, it allowed the focus of the populist campaign to remain on alcohol-related violence without shifting the debate back to a more narrow and punitive focus on 'individual' responsibility (particularly, that of Loveridge). ${ }^{6}$

Even in the absence of the media representing an 'ideal offender' (Christie 1986) the circumstances of Thomas Kelly's death had all the hallmarks of an event that would trigger a classic penal populist response: a specific event involving an 'innocent life' being taken, generating community outrage. However, as will be discussed below, classic 'law and order' responses have not taken centre-stage; rather we have witnessed what the Government described as a 'whole-of-government response' (O'Farrell, Hansard, 19 September 2012, p. 15301; see also Quilter 2013) to Mr Kelly's death. There were four main phases to this response.

\section{The Whole-of-Government Response}

(1) The Audit 
The first phase was announced less than ten days after Mr Kelly died, on 18 July 2012, and involved an immediate audit by the NSW Office of Liquor Gaming and Racing (OLGR) of the responsible service of alcohol registers of all 58 late trading licensed venues in Kings Cross. As will be discussed below, it was significant that the Government's first response to Mr Kelly's death was made by the OLGR - not by the Minister for Police or the Attorney General as would be more typical in a 'law and order' response. The audit announced was to have two stages. The first being to look at 'the nature and substance of incidents that have been occurring at Kings Cross licensed venues and the adequacy of existing incident and RSA reporting at each venue.' (Souris, Media Release, 18 July 2012) The second phase was to compare the registers with police incident reports and Bureau of Crime Statistics and Research (BOCSAR) data to check for under-reporting of violent incidents (Souris, Media Release, 20 July 2012). The implication was that these venues might be covering up irresponsible service of alcohol and worse, under-reporting violent incidents whether to avoid the "Three Strikes Legislation"7 or to avoid the "Violent Venues Scheme ${ }^{, 8}$ or for some other improper purpose. In this way, in undertaking the audit, a very public link was made by the Government between venues in the Kings Cross Precinct and alcohol related violence.

\section{(2) Liquor Licence Conditions and Education Campaigns}

The second phase of the Government's response, followed quickly after the audit. On 15 August 2012, the same day a formal tribute was made to Thomas Kelly in Parliament (Blair MP, Legislative Council, Hansard, 15 August 2012, p. 13705), the Premier moved to introduce a raft of restrictive licence conditions on the licensed venues in the Kings Cross Precinct. The licence restrictions were justified on the basis that the audit had uncovered 'a large disparity' in the registers of many venues (O'Farrell, Media Release, 15 August 2012). The conditions announced by the Premier among other things, importantly imposed restrictions on the type and amount of alcohol that could be sold on Friday and Saturday nights after midnight together with introducing new CCTV conditions covering entries/exits for venues trading past midnight (O'Farrell, Hansard, 15 August 2012, p. 13824; see also Souris, Media Release, 15 August 2012). These conditions, as will be discussed below, pick-up and introduce measures advocated for by the Coalition of Concerned Emergency Services Workers (composed of police, nurses, doctors and ambulance officers) in their Last Drinks Campaign (Coalition of Emergency Service Workers 2010).

On the same day as the licence conditions were announced by the Premier, George Souris JP MP, Minister for Tourism, Major Events, Hospitality and Racing also announced three alcohol education campaigns to be undertaken by the Government via the NSW Ministry of Health and OLGR (Souris, Hansard, 15 August 2012, p. 13826). The Minister attributed these initiatives to a 'pledge' given to David Anstee, a close friend of the Kelly family, who, on the family's behalf, was seeking ways to solve the problem of alcohol-related violence ((Souris, Hansard, 15 August 2012, p. 
13826). Thomas Kelly's father joined the Minister for the launch of the third education campaign (a resource developed by the OLGR and ultimately entitled, 'Out Tonight? Party Right') on 14 February 2013 (Souris, Media Release, 14 Feb 2013).

\section{(3) The 18 September 2012 Response}

The next month, on 18 September 2012, Premier O'Farrell announced the NSW Government's Ten-point plan for 'Cleaning up the Cross' (O'Farrell, Media Release, 8 September 2012). This Ten-Point Plan needs to be read alongside the September 2012 'NSW Government Response to Issues in Kings Cross' (the Response) (NSW Government 2012) which extends and further details the Ten-Point Plan. These plans set out a multi-faceted agenda incorporating responses under Compliance and Enforcement; Transport; and People and Places. Each of these areas of the Response sets the Government's legislative and other agendas in relation to intervention into alcohol-related violence in Kings Cross for the year to come and I will refer to these initiatives in more detail below.

(4) The 'Legislative' Phase September 2012 - October 2013

While it would be wrong to characterise the Government's actions as only legislative during this phase, nevertheless in the 12 months since announcing the Response a staggering seven pieces of legislation have been passed with explicit regards to $\mathrm{Mr}$ Kelly's death. In discussing the Response below, I make reference, where relevant, to the legislation introduced by the Government or action taken, to accomplish the plan in the period.

The first area, 'Compliance and Enforcement', was the most extensive with the Government's Response including:

- an expanded boundary for the Kings Cross Precinct and a freeze on new liquor licences for a further 3 years in the area (until 24 December 2015). These plans became law a mere two months later with the passing on 20 November 2012 of the Liquor Amendment (Kings Cross Plan of Management) Bill 2012 which commenced operation on 7 December 2012;

- prescribing the restrictive liquor licence conditions announced on 15 August 2012 through the Liquor Amendment (Kings Cross Plan of Management) Bill 2012. ${ }^{9}$ This Act amended both the Liquor Act 2007 and the Liquor Regulation 2008 (via the Liquor Amendment (Kings Cross) Regulation 2012) to prescribe in pt $5 \mathrm{~A}$ the, "Special licence conditions for premises in Kings Cross precinct". ${ }^{10}$ These conditions were also extended to all late night trading venues within the expanded Kings Cross Precinct. 
- implementation of linked ID scanners, to confirm and record identities of banned persons entering premises in the Kings Cross Precinct. These measures were incorporated into the Liquor Amendment (Kings Cross Plan of Management) Bill 2013, which received assent on 23 October 2013 and commenced operation on 6 December 2013. This Bill amends the Liquor Act 2007 (NSW) and the Liquor Regulation 2008 (NSW) to provide for the ID scanning of all patrons who enter high risk venues in the Kings Cross Precinct and for two new types of banning orders (a 48 hour ban and a 12 months ban) that will prohibit certain persons from entering licensed premises in Kings Cross (see Liquor Act 2008 (NSW) ss 116AA-116AF; Liquor Regulation 2008 (NSW) cls 40A, 41A and 53Q) .;

- the creation of a small bar licence defined as 'a bar catering for 60 or fewer patrons' (O'Farrell, Media Release, 18 September 2013) to 'promote diversity' and create a different 'business model for the industry' (Souris, Media Release, 19 September 2012). This initiative was enacted through the Liquor Amendment (Small Bars) Act 2013 (commencing on 1 July 2013);

- the trial of a sobering-up centre to service the precinct. In the end, three 12 month trial sobering-up centres were created when the Intoxicated Persons (Sobering Up Centres Trial) Act 2013 commenced operation on 24 May 2013;

- Supplementary policing at peak times, the cost of which to be contributed to by licensed premises in Kings Cross;

- All relevant staff of Kings Cross licensed venues to transition to Mandatory Responsible Service of Alcohol (RSA) Competency Cards by 1 March 2013 (enacted in the Liquor Amendment (Kings Cross Plan of Management) Bill 2012). A power to revoke RSA Competency Cards where an employee has committed a serious breach of their obligations to responsible service of alcohol was also enacted in the recent Liquor Amendment (Kings Cross Plan of Management) Bill 2013 which amended the Liquor Regulation 2008 (NSW) inserting the power in $\mathrm{Cl} 39 \mathrm{AA}$ and commencing operation on 6 December 2013;

- 'Operation Rushmore' led by NSW Police to 'target alcohol-related crime, antisocial behaviour and violent behaviour in public spaces in the lead-up to and over summer in Kings Cross.' (O'Farrell, Media Release, 18 Sept 2012) The first such 'blitz' occurred on Friday 28 September 2012 and continued over the October 2012 long weekend; and

- the use of drug detection dogs by police without warrant in Kings Cross and on all metropolitan and inter-city train lines. Ultimately, the Law Enforcement 
(Powers and Responsibilities) Amendment (Kings Cross and Railway Drug Detection) Bill 2012 provided for these measures which received assent on 29 October 2012.

The second part of the September 2012 Response entitled 'Transport', included: improvements to the major taxi rank servicing Kings Cross to increase the safety of taxi services; a trial of pre-paid taxis; an extension of late night bus services $;{ }^{11}$ and improved 'signage and way-finding' for patrons in the Cross (NSW Government 2012, p. 4). The pre-paid taxi legislation was introduced by Regulation and commenced on 12 October 2012: Pre-Paid Taxi Legislation: Passenger Transport Amendment (Kings Cross Taxi Fare Pre-payment) Regulation 2012 amending the Passenger Transport Regulation 2007. The Mayor also announced the city had been given $\$ 200,000$ from the federal government to install dedicated CCTV and improved lighting at the major taxi rank on Bayswater Road taxi servicing Kings Cross.

The final part of the Response, 'People and Places', included: a police officer being stationed in the Sydney CCTV control room every Friday and Saturday night; the delivery (in conjunction with the City of Sydney Council) of a co-ordinated education and public information campaign on risky drinking, transport services and complaints systems; and support for the Kings Cross Festival in early November 2012, to encourage a diversity of people to use the Cross.

The point of this detailed catalogue is to highlight the fact that, in the 15 months since Thomas Kelly was killed, the Government has pursued a sophisticated and multi-faceted policy program to deal with the problem of alcohol-related violence in Kings Cross. I want to draw attention to the remarkable nature of this response and what is particularly noteworthy, is that it is a dramatic departure from the typical "law and order' responses we have historically witnessed in NSW when a specific event triggers community outrage. Indeed, of the seven pieces of legislation passed since Mr Kelly's death, only one could be said to be of the classic penal populist kind - the use of drug detection dogs without warrant.

In the next Part of this article, I want to explore the important question to which this account gives rise: how did a single act of extreme violence trigger such a multifaceted and nuanced response by the Government to the problem(s) of alcoholrelated violence? Moreover, what were the conditions that made it possible for this to happen when one might have expected (given the history in NSW) a classic penal populist/law and order response? The first point to recognise is that prior to $\mathrm{Mr}$ Kelly's death, the problem of alcohol-related violence in Kings Cross had been the subject of research, ${ }^{12}$ media coverage ${ }^{13}$ and political discussion. ${ }^{14}$ While in the period prior to Mr Kelly's death (January 2007 - December 2011) reported rates for violent offences declined and non-domestic assaults were stable in the Sydney area (Goh \& Moffatt 2011), the NSW Government's Violent Venues Scheme and the Three Strikes Legislation (discussed above) demonstrate that the government was already addressing the relationship between alcohol-related violence and licensed 
premises. The need for complex and nuanced responses specifically in the Kings Cross Precinct was well articulated by Clover Moore, the Lord Mayor of the City of Sydney, and then member for Sydney, during the debate in October 2011 about the Three Strikes Bill:

Sydney has a thriving nightlife but it needs to be safe for everyone. Alcoholrelated violence and antisocial behaviour are a serious ongoing problem, particularly in the inner city. In Kings Cross last year the City of Sydney recorded 80 violent incidents in just one hour between 1.00 a.m. and 2.00 a.m. on a Sunday - and police tell me such incidents are happening every weekend. Making our night-time economy safe is a priority. Our current approaches are very limited and crime safety experts, police, emergency workers, venue patrons and city residents all want something to be done. Having high quality, well-managed and safe late-trading premises is central to our reputation as a safe place to visit. (Moore, Hansard,18 October 2011, p. $6711)^{15}$

In other words, the problem of alcohol-related violence in Kings Cross did not come into being in July 2012. However, prior to Mr Kelly's death there had not been a cohesive focus for the range of disparate issues associated with the problem in Kings Cross. Following Mr Kelly's death, as will be discussed below, a populist movement of a non-punitive variety took hold of the debate unified around his popular identity. In the discussion below, I will organise the telling of the story behind the Government's response around four key themes, drawing on Laclau and other accounts of populism: the role of the media; the unifying effect of the emotions; the importance of populist rhetoric; and finally, the consolidation of the campaign through a popular identity.

\section{The populist campaign}

\section{The framing power of the media}

The media are often targeted in critiques of penal populism for misinforming the public and fostering punitive attitudes. The coverage since Mr Kelly's death in July 2012 has been anything but. The media campaign during the first four-to-six weeks after his death was prolific and I make mention of only four examples of the many, to illustrate how the media was actively involved in framing the problem and, subsequently, the solutions, as one of alcohol related violence.

Less than a week after Mr Kelly's death, on 12 July 2012, Fairfax launched its Safer Sydney campaign to 'champion civility over thuggishness and rudeness, to restore Sydney as a safe place' (SMH, 12 July 2012). Thereafter, stories relating to Mr Kelly's death and what quickly became synonymous with it, alcohol-fuelled violence, were led under the banner 'Safer Sydney'. Five days later on 17 July 2012, Fairfax hosted a packed public forum as part of the 'Safer Sydney' campaign, on 'How to tackle violence on the city's streets after dark?', at the Town Hall (the Forum). This 
event had been widely advertised through the Sydney Morning Herald under the 'Safer Sydney' banner. A broad range of representatives from politicians (including Malcolm Turnbull MP (the federal MP for the area), George Souris JP MP (the Minister with responsibility for hospitality and liquor licencing) and Lord Mayor Clover Moore), police (including Assistant Commissioner Mark Murdoch), the Director of NSW Bureau of Crime Statistics and Research (BOCSAR), Don Weatherburn, representatives from the hotel industry (including Doug Grand, Kings Cross Licensing, and Paul Nicolau, NSW CEO of Australian Hotels Association), to business owners and an estimated 600 community members. Notably, the typical Government leaders for law and order crises (the Attorney General and Police Minister) were not present. The event was streamed live over the internet and what quickly became clear was that the majority attending the Forum believed that 'alcohol' and its availability were the problem. This was made explicit when Assistant Commissioner Murdoch, to a roar of applause from the audience, said:

I'm going to cut straight to the chase. It's the abuse and availability of alcohol that's the problem. (SMH, 21 July 2012)

Weatherburn backed up this claim, making it clear that drugs (such as methamphetamines) were not the issue in the Cross but rather alcohol was. He indicated that $86 \%$ of assaults that occur within a $500 \mathrm{~m}$ radius of Kings Cross are alcohol related; that violence is concentrated on two streets, Darlinghurst Road and Bayswater Road; and that the violence occurs between the hours of 12am and 3am. (SMH, 19 July 2012, p. 1)

The Forum also usefully articulated a series of related issues exacerbating the problems with alcohol and top of that list was the lack of public transport in the area. As Turnbull said at the Forum:

It's clearly nuts to have venues trading, people up there drinking until three or four in the morning and having the last train ending at a quarter to two. (AAP Bulletins, 17 July 2012)

Assistant Commissioner Murdoch had previously articulated this problem, 'we get all these people up to the Cross but then stop the transport - leaving no motivation to leave the area and go home' (SMH, 13 July 2012, p. 1). Other related issues that emerged from the Forum were the late-night trading hours and density of venues in the area and excessive alcohol consumption. This Forum operated to frame the mood and themes for the ensuing debates that focused squarely on the need for a multi-faceted, co-ordinated response to alcohol-related violence.

On 16 July 2013, the ABC's 7:30 Report ran, 'What does a night in Kings Cross look like?' making mention of Thomas Kelly's death as the cause for the segment. Adam Harvey of the $A B C$, spent the night in the Cross and spoke with a broad range of persons from young people going out that night, to police including Assist Commissioner Murdoch, owners of nightclubs, Doug Grand from Kings Cross Licensing, private security guards, the Kings Cross Residents Association and the 
Head of Emergency at St Vincent's Hospital. Again the most explicit themes to emerge from the segment were the lack of late night transport, excessive alcohol consumption, Australia's drinking culture and its relationship to alcohol related violence.

Finally, on 26 July 2012, News Ltd launched its Real Heroes Walk Away campaign. Mr Kelly's death was again the catalyst for the campaign which is aimed particularly at young men aged 15-25 years. The message is a simple one: 'When trouble starts, walk away. There is nothing heroic about getting involved in a fight. Heroes don't escalate violent situations, they defuse them.' (Mcllveen 2012) The focus of the campaign was clearly on 'preventative' strategies not punitive measures. In September 2012, Ralph Kelly endorsed the Real Heroes Walk Away campaign, urging all Australians to support it.

Importantly, in these early days and subsequently, there was no attempt in the media or otherwise to shift the debate back to a more traditional (and narrow) law-and-order focus. ${ }^{16}$ The Police certainly did not try to own the issue as a 'law and order' one and there were no cries made for more police powers and resources. For instance, Assistant Commissioner Murdoch summed up the problems as 'too many venues, their late night trading and the lack of public transport options to get people home.' (SMH, 13 July 2012, p. 1) These problems he said were known to the state government, local council, the venues and the relevant agencies and now was the time to 'stop the buck-passing and get on with fixing it.' (SMH, 13 July 2012, p. 1) Ironically, in the immediate aftermath of Mr Kelly's death, it was only the NSW Chief Executive of the Australian Hotels Association, who attempted to suggest that greater policing in the area would solve the issues, calling for a New York-style zero tolerance on crime in the Cross (SMH, 18 July 2012, p. 1). This was never accepted as the appropriate solution nor did the Government act upon the suggestion.

\section{Emotion as a unifying force}

One of the suggested 'remedies' to penal populism discussed above, is to eschew popular emotionalism and return to a more rational crime policy debate. As I have also argued above, this approach fails to mobilise the potentially positive and progressive role that popular emotionalism may play. When we look at the public discourses in the immediate aftermath of Thomas Kelly's death it is clear that an emotional driver lay behind the momentum to do something positive. Mr Kelly's death was variously described as a tragedy (SMH, 14 July 2012), a senseless death (Souris, Hansard, 15 August 2012, p. 13826), a 'shocking death' (Upton, Hansard, 19 Sept 2012, p. 15310), one provoking sadness (Upton, Hansard, 19 Sept, 2012, p. 15310), sympathy (Newcastle Herald, 23 July 2012) and grief (SMH, 18 July 2012) but also anger, revulsion (AFR, 21 July 2012) and outrage (Herald Sun, 22 August 2012). Often at such moments a more polarising and demonising economy enters the public discourse as discussed in part one of this article, but what became a common feature in this instance, particularly through representations in the media, 
was that these emotions operated to unify the people against a common 'enemy' of 'alcohol-fuelled violence'. Such sentiments are reflected in the Premier's announcement in Parliament of the 15 August 2012 licence conditions:

Mr MATT KEAN: My question is addressed to the Premier. What is the Government's response to the recent audit of licensed late-trading venues in Kings Cross?

Mr BARRY O'FARRELL: I thank the member for Hornsby for his question. I know the answer to this question will be of interest to everybody following the tragic death last month of Thomas Kelly. Whether it is because we go there, or because our children or our grandchildren go there, or because we care about what happens in our city, concerns about the safety of people who visit Kings Cross are an issue for almost every one of us. The alcohol- and drugfuelled incidents that occur at Kings Cross and their impacts upon innocent individuals and their families are a blight upon this city. ..

[after announcing new measures to curb alcohol-related violence in Kings Cross]

... the Government makes no apologies for seeking to improve the safety and amenity of Kings Cross. The memory of Thomas Kelly deserves no less. (O'Farrell, Hansard, 15 August 2012, pp. 13823-4)

From a very early point, the emotional responses to Mr Kelly's death did not lead to a punitive public but for a call for real and enduring action:

Enough with the hand-wringing that goes back generations. The city demands action. Local and state governments, too ready to shrug impotently at a problem beyond any one agency to remedy, must put heads and resources together, looking not at policing and entertainment venue planning in isolation but how each buttresses the other. ... An event sometimes shakes society from its slumber, demanding action over indignation. The death of Thomas Kelly ....is one such event. (SMH, 12 July 2012; see also Gold Coast Bulletin, 4 August 2012)

Polling results undertaken by the FARE released on 30 August 2012 ahead of a community forum that evening to discuss alcohol-related violence following $\mathrm{Mr}$ Kelly's death, backed up this call. The polling indicated that $77 \%$ of adults in NSW believe more needs to be done to reduce alcohol harms and $80 \%$ of NSW adults believe NSW has a problem with excess drinking and alcohol abuse. The results also showed that there is a perception that government, the alcohol industry, and pubs and clubs are not doing enough to address the problem (FARE 2012). FARE claimed the NSW 'community is united in its desire for action to tackle alcoholrelated problems.' (FARE, Media Release, 30 August 2012)

This call for action was also echoed by a range of professionals and organisations. For instance, the Coalition of Concerned Emergency Services Workers called for 
real action through the institution of the restrictive measures of the Last Drinks campaign which had been successfully used in Newcastle in 2008 to reduce alcohol related assaults. These measures include: the imposition of a lockout from 1am on all hotels and bringing forward the closing time for venues to 3am; a prohibition on the sale of shots and mixed drinks stronger than $5 \%$ alcohol by volume after $10 \mathrm{pm}$; and a prohibition on the sale of more than four drinks to any patron at one time and a requirement to provide free water stations on every bar (Coalition of Concerned Emergency Services Workers 2010, pp. 3-4). These measures were also supported by the two peak bodies respectively for doctors and police, the AMA (The Advertiser, 28 September 2012; Sun Herald, 16 September 2012) and the Police Association (Daily Telegraph, 12 July 2012). FARE called for the Government to address the problem of alcohol harms NSW-wide through its '10 Point Plan to Reduce Alcohol Harms in NSW' released on 25 August 2012. The ten-points include restrictions on trading hours, density of venues, pricing of alcohol and introducing appropriate transport (FARE 2012). The National Drug and Alcohol Research Centre, UNSW, argued for the need to attack the causes of alcohol related violence: the availability of alcohol; advertising; and price (SMH, 17 July 2012: 9).

Finally, these calls were echoed in Parliament:

The Government is determined to ensure that the tragic death of Thomas Kelly leads to action from not just the State Government but also the City of Sydney to minimise the chances of such an incident happening again. (O'Farrell, Hansard, 15 November 2012, p. 16979; see also Brookes, Hansard, 24 October 2012, p. 16368; MacDonald, Hansard, 12 September 2013, p, 23367)

These voices significantly overlapped in relation to the key problem of addressing alcohol and its (over)availability. This focus was also powerfully legitimised by $\mathrm{Mr}$ Kelly's family. Unlike the many times when a family who loses a loved one to a crime is presented in the media as grief stricken but also wanting 'justice'/retribution, the Kelly's made it clear from the outset that they wanted their son's life to 'make a difference'; for something good to come of this. Since Thomas' death, the Kelly's have advocated for strategies to reduce alcohol related violence, perhaps most notably in establishing the Thomas Kelly Youth Foundation in December $2012 .{ }^{17}$ On its website, the Foundation appeals to 'the people' to take action against alcoholfuelled violence. While populist, it is without the punitive edge, calling for 'real change', listing policing and sentencing as strategies but also states, 'We need effective measures to address the issue in a meaningful and long-term manner' calling on the State government to 'reduce the trading hours of licensed venues, set limits on the number of new liquor licences, and provide the community with a greater say in the determination of new liquor licences.'

Importantly, the action called for across the spectrum was for a more nuanced, complex and enduring response, in stark contrast to the often 'big splash' but minimal effects, law and order responses we are used to seeing from State governments. 


\section{Rhetorical devices}

From an early point the campaign came to be known by the powerful popular trope of 'alcohol-fuelled violence' - often replacing the more accurate descriptor 'alcohol related violence' evoking the empirical link that has been demonstrated to exist between alcohol and violence (eg Burgess \& Moffatt 2011). This expression was used in the press, by related organisations and in the Parliament. As poststructuralists and others have argued language does not simply describe a preexisting reality but is involved in actively constructing it. The trope, 'alcohol-fuelled violence', was important for three reasons relating to how it contributed to constructing 'the problem' and the solutions to follow.

First, the expression 'alcohol-fuelled violence' operates rhetorically to posit 'alcohol' as the problem and those that 'fuel' it as the enemy - arguably the liquor industry. In this way, rhetorically the problem was framed almost from the outset as one that related to alcohol and those who (irresponsibly) supply it. Returning to Laclau's work, this simplified the political landscape replacing a complex set of issues with a single problem. It also operated to produce a binary between 'the people' (as described by the Premier above) and the liquor industry which will be discussed further below. ${ }^{18}$

Secondly, while the language was populist and emotionally charged, linguistically the language does not foster the classic punitive outcomes often associated with penal populist rhetoric such as 'three strikes' legislation. The trope, 'alcohol-fuelled violence', if anything operates to remove individual responsibility that could have triggered a more classic demonising of such individuals as Loveridge or others who commit similar acts of violence. As has been discussed above, this is consistent with the fact that prior to the sentencing proceedings, Mr Loveridge was not discussed in the media stories about Mr Kelly's death and certainly no reference was made to his criminal past. The refrain ' alcohol-fuelled violence' suggests that these are not bad people per se - they are our sons, our grandsons, our relations as the quote from the Premier above suggests - it is rather the 'alcohol' that fuels them to act violently and those doing the 'fuelling' are to blame.

Finally, and perhaps most importantly, having rhetorically framed the debate as one relating to alcohol and its supply, this provided the conditions of possibility for the more nuanced solutions documented above - and, importantly, made other more punitive responses unintelligible. As the overview of the Government's responses demonstrates, in the past 15 months since Mr Kelly's death the emphasis has been on the availability (and strength) of alcohol and the role licensed venues in Kings Cross (irresponsibly) play in fostering that availability. This was the resonating message in undertaking the audit and in its results; it was the reason for the licence conditions being imposed in the Kings Cross Precinct; for the creation of the small bar licence; and the implementation of ID scanners. 
The power of this campaign to frame the debate and its solutions as one about alcohol, is reflected in the fact that in the early days following Mr Kelly's death, it was the Minister for Tourism and Hospitality, Souris JP MP who appeared as the face of the Government at the Forum (discussed above) and in so many of the media and Parliamentary debates that followed. More typically, a killing would be framed as a law and order issue, with the classic custodians being the Minister for Police or the Attorney General - yet we heard little from them in this campaign. By contrast, since Mr Kelly's death, 20 of the 40 official media releases from the Minister for Tourism and Hospitality refer directly to Mr Kelly and/or to alcohol-related violence.

The successful nature of the campaign is demonstrated in the distance Souris JP MP travelled from his first comments ten days after the death of Mr Kelly:

[Souris JP MP] said it was possible the incident [Mr Kelly's death] was unrelated to alcohol and that licensing should not be the sole focus.

"I want to be careful not to create a scenario in Sydney where we drive a lot of the industry underground," ...

Mr Souris described Mr Kelly's death as "very sad and unfortunate" but pointed out that the assault occurred at the relatively early time of $10 \mathrm{pm}$. "It wasn't at a licensed venue, it wasn't immediately at the front door of a licensed venue," he said. (Canberra Times, 17 July 2012)

The contrast between these early words and what his Government has done in the past 15 months is testimony to just how effective the campaign has been. It is also a reflection of the potential power of mobilising the public's emotions and the power of rhetoric. If we look at Mr Kelly's death 'rationally' as is often advocated by critics of penal populism, are not Souris' conclusions correct? Could the nuanced and multifaceted response have been advocated? Mr Kelly did not die after a big night out at or near a licensed venue; he was not affected by alcohol; it was relatively early in the evening (10pm); he did not have problems with transport; he did not have a chance to walk away; and it was only in September 2013 that the perpetrator's alcohol affected state (none of which appears to have been consumed in the Kings Cross Precinct) became public knowledge. Rationally, the solutions we have witnessed have been only tangentially related to Mr Kelly's death - added to all of this, is the fact that assaults at or near licensed premises during the same period have been declining (Snowball \& Spratley 2013; Goh \& Moffatt 2012, 2013).

\section{Popular identity}

The above discussion makes it clear that there were a large number of voices and organisations involved in this campaign, many of whom have different agendas, represent different interests and have been working for years on these issues with significant knowledge and experience, yet often with little traction. How was it possible to bring them all together at a particular moment and to keep them united in the past 15 months in a primary goal of tackling 'alcohol fuelled violence'? I would suggest in Laclau's terms, Mr Kelly became the 'popular identity' unifying what was 
otherwise a series of differential claims - arguments over planning and licensing laws; public transport; education campaigns; restrictions on availability and type of alcohol etc. It is also important that through this process political alignments are reconfigured - for instance, the police are often aligned with 'law and order' campaigns but here were realigned with doctors and other emergency service workers in relation to harm minimisation strategies.

Thomas Kelly was the true innocent, the 'ideal victim' (Christie 1986), he was simply in the wrong place at the wrong time, and everyone could relate to the randomness of the attack. Mr Kelly could be anyone's son, brother, partner, husband, grandson. For so many news stories though, we know very little about Thomas Kelly, other than he was a young man who was just beginning to find his 'feet' when he was tragically killed. Yet in this gap, Thomas Kelly has been 'filled', in Laclau's terms, and comes to have an undifferentiated fullness invested with a multiplicity of demands which he unifies in the fight against alcohol-related violence. If we evaluate the content of the different claims and responses as discussed above, these claims were arguably only tangentially related to Mr Kelly's death. Yet very quickly he became the popular identity for this campaign, a synechdoche, 'standing in' for, alcohol-related violence in the Cross.

The collocations of 'Thomas Kelly' with alcohol related violence are numerous to the point where in the public discourse his name stands in for it (and vice-versa). As Gross, Moore and Threadgold argue, to 'collocate' is not simply to 'co-occur' but rather phrases co-occur because they are seen to belong to the same field or subject-matter, share meanings and to belong together (Gross et al 2007, p. 25). Nowhere is this connection made more explicit than in Parliament where his name is mentioned in relation to literally every piece of legislation passed by the Government in its response to alcohol-related violence. The examples are numerous, ${ }^{19}$ and here I mention only the Premier's link between Mr Kelly and the Government's legislative measures to combat alcohol related violence in the Cross:

GABRIELLE UPTON: My question is addressed to the Premier. What are the latest developments in the Government's efforts to clean up Kings Cross?

Mr BARRY O'FARRELL: I thank the member for Vaucluse for her question and for her interest in this important matter, which was brought into sharp relief by the death of Thomas Kelly in July. The Government is determined to do what it can to ensure that such an event is not repeated. Yesterday legislation was passed by this Parliament to help achieve our goal of trying to minimise the risks faced by people young and old who simply want to head off to Kings Cross to have a good night out. The Liquor Amendment (Kings Cross Plan of Management) Bill 2012 implements the first stage of the Government's response to the death of Thomas Kelly and will be in place in time for the summer holidays, next month. (Hansard, 15 November 2012, p. 16979) 
Mr Kelly's popular identity continues to symbolise this campaign through the work of the Thomas Kelly Youth Foundation. The Foundation's three major initiatives since formation include: a citizen's jury to make recommendations to Parliament on 'How we can ensure we have a vibrant and safe Sydney nightlife?' commencing in February 2014; the development of a 'TAKE KARE Safe Zone' in Darlinghurst for intoxicated youths to seek assistance (in the form of water, calls to family/friends, thongs to replace high heels, transport or even hospitalisation ${ }^{20}$; and finally, funding for ten additional CCTV cameras to be known as 'TK: Take Kare' - TK being Thomas' nickname among his friends. Each of these initiatives in Thomas Kelly's name continue to symbolise the campaign against alcohol-related violence.

\section{Conclusion}

In this article I have argued that populism is not by definition a punitive influence on crime prevention policy. The Thomas Kelly case study illustrates that populism can have a constructive impact on Government policy and legislation. The central role that a populist campaign played in framing the problem and, subsequently, the solutions, as one of 'alcohol related violence' produced the conditions of possibility for the nuanced and complex set of responses made by the Government. It also provided the conditions for a powerful realignment of the police with other emergency service workers away from 'law and order' politics and towards harm minimisation strategies. This case study invites further research into alcohol related violence and other crime problems, in order to shed further light on the optimal conditions for generating constructive policy responses that are informed by nonpunitive populism. Key insights offered by the Thomas Kelly case study are to take seriously rather than dismiss the rhetoric of populism and the potential of centring the emotions, the role of the media and the unifying power of a popular identity.

\section{Notes}

\footnotetext{
1 The author is indebted to Hogg's most recent work which drew attention to Laclau's thesis on populism (see Hogg 2013, pp. 113-4).

2 Kings Cross has a long-standing reputation as a 'party precinct' of Sydney; the Lord Mayor indicates that on an average Saturday, Darlinghurst Rd (one of the main streets in the Cross) has 21, 600 people from $11 \mathrm{pm}$ to 3am: Moore, 17 July 2012; see also Souris, Hansard, 24 October 2012, p. 16401.

${ }^{3}$ A 'king hit' is 'generally characterized by a single blow to the head, incapacitating a victim causing them to fall to the ground becoming unconscious. This may be either due to the punch itself, or as a result of the impact between the head and the ground.' Pilgrim, Gerostamoulos \& Drummer 2013.

${ }^{4}$ For a discussion of the outrage that the sentence provoked and the NSW Government's 'law and order' response to the sentence see Quilter 2014.

${ }^{5}$ Indeed, the secrecy that appears to have surrounded this information is reflected in the fact that the Australian Hotels Association (AHA) NSW branch submitted an application to NSW Police seeking a copy of the background to Mr Kelly's death including Mr Loveridge's movements prior to and following the assaults: SMH, 25 August 2013.

${ }^{6}$ Until Justice Campbell's judgment was handed down on 8 November 2013, the media did not report on Mr Loveridge's background including his criminal record which included offences of taking and driving a car without the consent of the owner, damaging property, assaulting an officer and affray. More importantly, Mr Loveridge had a record for violence (assault occasioning actual bodily harm) and was on conditional liberty at the time of committing the manslaughter: see $R v$ Loveridge [2013],
} 
[25]-[29]. Had this background information been released it is possible that the progressive populist campaign may have taken a different turn. Certainly events following Mr Loveridge's sentence have demonstrated a more typical punitive response by the media, the public and the NSW Government: see Quilter 2014. By way of comparison it is noted that a very different media, public and governmental response arose in relation to the (almost) contemporaneous rape and murder of Jill Meagher in September 2012 in Melbourne, Victoria. The perpetrator of that crime, Adrian Bayley, was on parole at the time of the offence and had a long criminal record including for sexual violence - so much so that he was named a 'recidivist violent sexual offender' by Nettle JA in sentencing Bayley: see The Queen v Bayley [2013] VSCA 295, [17]. In addition to the very punitive response by the public to this offender, the Victorian Government focused on problems with the parole system generally responding with a more typical 'law and order' response: see for instance, Callinan 2013; and the Justice Legislation Amendment (Cancellation of Parole and Other Matters) Bill 2013.

${ }^{7}$ See the Liquor Amendment (3 Strikes) Act 2011 which inserted a new pt 9A, 'Disciplinary action - 3 strikes' into the Liquor Act 2007. This enabled the Independent Liquor and Gaming Authority to impose restrictions on licences including suspension and cancellation according to the number of strikes.

${ }^{8}$ The violent venues list relates to the number of recorded violent incidents at a venue and once certain thresholds are reached (commencing with more than 12 -18) certain licence restrictions are imposed by the OLGR.

${ }^{9}$ It is noted that the AHA attempted to prevent these conditions being made law with one of the largest venues in the Cross, seeking and obtaining at first instance, an injunction in the Supreme Court. The State successfully appealed the injunction: see Director-General Department of Trade \& Investment, Regional Infrastructure and Services v Lewis [2012] NSWCA 436

${ }^{10}$ For further detail on the conditions see Quilter 2013. It is noted that the big concession made to the liquor industry was the incorporation of provisions to exempt certain licensees on application: see cl $53 \mathrm{E}, 53 \mathrm{~F}$ and $53 \mathrm{H}$.

${ }_{11}$ In Parliament on 15 November 2012, O'Farrell indicated that 32 new route 999 bus services every weekend to and from Kings Cross had been introduced being 200 additional bus services and that the N100 express NightRide had offered an additional 16 late-night weekend services carrying around 1000 people out of the Cross to connect with other transport services.

${ }^{12}$ While there was no particular upswing in reported violence offences in the Sydney area in the two years leading up to Mr Kelly's death (see Goh \& Moffatt 2011), there was a strong focus in the research on the correlation between the density of licensed premises generally (but also specifically in Kings Cross) and assaults: see for instance, Donnelly, Pynton, Weatherburn, Bamford \& Nottage 2006; Urbis JHD 2006; Fleming 2008; Fitzgerald, Mason \& Borzycki 2010; Burgess \& Moffatt 2011; Shakeshaft, Love \& Wood 2011; Payne \& Gaffney 2012.

${ }_{13}$ A Factiva search of major Australian media stories on alcohol and violence in Kings Cross reveals that between 1 July 2013 and 30 June 2012 there were approximately 30 stories - significantly less than the 180 stories in the following year (1 July 2012 - 30 June 2012) which includes the period after Mr Kelly's death. Analysing these articles indicates that some of the initiatives introduced by the NSW Government following Mr Kelly's death had been under discussion in some form in this earlier period. For example, articles relate to: the NSW license freeze for Kings Cross pending a study commissioned by NSWOLGR on the effects of density of venues on assault, drink-driving and antisocial behaviour (Silmalis, Sunday Telegraph, 8 April 2012); police concerns over glassing incidents including in Kings Cross (see Chambers \& Klein, Telegraph, 12 August 2011); calls by the police and other groups for the institution of the Last Drinks measures in Kings Cross (Hansen, Sunday Telegraph, 20 November 2011); discussion of the NSW Government's Three Strikes legislation and the Violent Venues Scheme (see Nicholls, SMH, 2 September 2011); discussion of small bars as a solution to alcohol related violence (see Olding, SMH, 9 April 2012); and the formalisation of the Kings Cross Licensing Accord Association with its members proposing to formalise a list of banned people from venues, introduction of ID scanners as a requirement of entry and a radio network with premises being able to alert private security and police of trouble (see Howden, SMH 1 August 2011). It is noted that many of these initiatives were later taken up in the NSW Government's response to Mr Kelly's death.

${ }^{14}$ See for instance, discussion in the NSW Parliament of the: Liquor Amendment (3 Strikes) Bill 2011 (No 2) (Lynch MP, Hansard, 19 October 2011, p. 6711); the Violent Venues Scheme (Souris MP, Hansard, 23 November 2011, p. 7737) and the Summary Offences Amendment (Intoxicated and Disorderly Conduct) Bill 2011 (Searle MP, Hansard, 4 August 2011, p. 3606). 
${ }^{15}$ Although it is also noted that in the period prior to Mr Kelly's death Kings Cross featured as a 'success' story when Souris MP indicated, 'For the first time there are no level 1 or level 2 venues in Kings Cross' on the Violent Venues list (Souris MP, Hansard, 23 November 2011, p. 7737).

${ }^{16}$ This is very different to the media coverage of similar one-punch deaths in Queensland between 2006-2009 as documented by Burke who describes the media as setting off a 'moral panic' about youth behaviour: see Burke 2010.

17 The Thomas Kelly Youth Foundation was launched with great fanfare as a fundraiser at The Star Casino, Sydney, on 19 September 2013 with celebrities, performers, politicians, the media and the academy (Sydney University).

${ }^{18}$ In asserting this, the author is not, however, naïve as to the power exercised by the liquor industry over the Government. The concessions made to the liquor industry in relation to the recent sale and promotion of alcohol guidelines is just one example: see NSW Office of Liquor Gaming and Racing, Liquor Promotion Guidelines, July 2013.

${ }^{19}$ For other collocations of the name 'Thomas Kelly' with government initiatives see the Premier's announcement of the liquor licence restrictions (O'Farrell, Hansard, 15 August 2012, p. 13823); the discussion of the Kings Cross Management Plan (O'Farrell, Hansard, 18 September 2012, p. 15301; and O'Farrell, Hansard, 15 November 2012, p. 16979; see also Souris, Hansard, 24 October 2012, p. 16401; Brookes MP, Hansard, 24 October 2012, p. 16368); the announcement of the Government's alcohol education campaigns (Souris, Hansard, 15 August 2012, p. 13826); the discussion of initiatives to improve transport to Kings Cross (O'Farrell, Hansard, 16 August 2012, p. 13970); the explicit mention in debate in relation to the Alcohol Beverages Advertising Prohibition Bill 2013 (MacDonald, 12 September 2013, Hansard, p. 23367); the motion by Upton to support the NSW Government action in addressing alcohol and drug-related violence in Kings Cross (Upton MP, Hansard, 18 September 2012, p. 15310); in relation to the Liquor Amendment (Small Bars) Bill 2013 (Issa, Hansard, 28 February 2013, p. 18293); and in relation to the Law Enforcement (Powers and Responsibilities) Amendment (Kings Cross and Railway Drug Detection) Bill 2012. Even where his name is not expressly used in Parliament, it is evoked from the collocation with 'alcohol related violence'. See for example, reference in the second reading speech to the Intoxicated Persons (Sobering Up Centres Trial) Bill 2013 (Gallacher, Hansard, 19 March 2013, p. 18741) and the discussion of the Liquor Amendment (Small Bars) Bill 2013 (Souris, Hansard, 18 February 2013, p. 18293).

${ }^{20}$ These may be compared to the 'Chill Out Zones' used in Queensland as part of the Drink Safe Precincts trial: see Queensland Government, (2013) Drink Safe Precincts: Evaluation update: 18 months of the trial' May 2013.

\section{References}

Alexander, C. (2013) The party's over: which clubs have the most members? Crikey, 18 July 2013 accessed at http://www.crikey.com.au/2013/07/18/the-partys-overwhich-clubs-have-the-most-members/?wpmp_switcher=mobile

Arditi, B. (2007) Politics on the Edges of Liberalism: Difference, Populism, Revolution, Agitation. Edinburgh: Edinburgh University Press.

Bottoms, A. (1995) The Philosophy and Politics of Punishment and Sentencing. In C. Clarkson \& R. Morgan (Eds), The Politics of Sentencing Reform. Oxford: Claredon.

Brown, D. (2013) Criminalisation and Normative Theory. Current Issues in Criminal Justice (forthcoming)

Burgess M and Moffatt S (2011) The Association between Alcohol Outlet Density and Assaults on and around Licensed Premises. Crime and Justice Bulletin No 147 
Burke, L. (2010) One Punch can Start Moral Panic: An Analysis of News Items about Fatal Assaults in Queensland Between 23 September 2006 and 28 February 2009 Queensland University of Technology LJJ, 10, 87-105.

Callinan, I. AC (2013) Review of the Parole System in Victoria. July 2013

Canovan, M. (1981) Populism. London: Junction Books.

Canovan, M. (1999) Trust the People! Populism and the Two Faces of Democracy. Political Studies, XLVII, 2-16.

Canovan, M. (2005) The People. Cambridge; Malden, MA: Polity.

Christie, N. (1986) The Ideal Victim. In E. Fattah (Ed), From Crome Policy to Victim Policy. Basingstoke: Macmillan.

Coalition of Concerned Emergency Services Workers (2010) Last Drinks: A Coalition of Concerned Emergency Services Workers, Keep Our Cops

http://www.keepourcops.org.au/Media/Police_alcohol_report_mar2010.pdf

Cullen, F., Fisher, B. \& Applegate, B. (2000) Public Opinion about Punishment and Corrections Crime and Justice, 27, 1-79.

Donnelly, N., Poynton, S., Weatherburn, D., Bamford, E. \& Nottage, J. (2006) Liquor outlet concentrations and alcohol-related neighbourhood problems Alcohol Studies Bulletin, No. 8

Dzur, A. (2012) Punishment, Participatory Democracy, and the Jury. New York: Oxford University Press.

Dzur, A. (2010) The Myth of Penal Populism: Democracy, Citizen Participation, and American Hyperincaceration. The Journal of Speculative Philosophy, 24, 354-379.

Fitzgerald, J., Mason, A. \& Borzycki, C. (2010) The Nature of Assaults Recorded on Licensed Premises Crime and Justice Statistics, No 43.

Fleming, J. (2008) Rules of Engagement: Policing Anti-Social Behaviour and Alcohol-Related Violence in and around Licensed Premises NSWBOCSAR

Foundation for Alcohol Research \& Education (2012) Foundation for Alcohol Research and Education 10 Point Plan to Reduce Alcohol Harms in NSW.

Freiberg, A \& Gelb, K. (Eds) (2008) Penal Populism, Sentencing Councils and Sentencing Policy. Annandale, NSW: Hawkins Press.

Freiberg, A. (2001) Affective versus Effective Justice: Instrumentalism and Emotionalism in Criminal Justice. Punishment and Society, 3, 265-278. 
Freiberg, A. (2008) The Victorian Sentencing Advisory Council: incorporating community views in the sentencing process. In A. Freiberg \& K Gelb. (Eds) (2008) Penal Populism, Sentencing Councils and Sentencing Policy. Annandale, NSW: Hawkins Press.

Garland, D. (2001) The Culture of Control. Oxford: Oxford University Press.

Garland, D. (2000) The Culture of High Crime Societies: Some Preconditions of Recent 'Law and Order' Policies. British Journal of Criminology, 40, 347-375

Goh, D. \& Moffatt, S. (2011) New South Wales Recorded Crime Statistics 2011. NSW BOCSAR

Goh, D. \& Moffatt, S. (2012) New South Wales Recorded Crime Statistics 2011. NSW BOCSAR

Goh, D. \& Moffatt, S. (2013) New South Wales Recorded Crime Statistics 2011. NSW BOCSAR

Gross, B., Moore, K., \& Threadgold, T. (2007) Broadcast News Coverage of Asylum April to October 2006: Caught Between Human Rights and Public Safety. Cardiff School of Journalism, Media and Cultural Studies, Cardiff University.

Hogg, R. (2013) Punishment and "the People": Rescuing Populism form its Critics. In K. Carrington, M. Ball, \& E. O'Brien (Eds), Crime, Justice and Social Democracy: International Perspectives (pp. 105-119). Hampshire, UK: Palgrave Macmillan.

Hogg, R. \& Brown, D. (1998) Rethinking Law and Order. Australia: Pluto Press.

Hutton, N. (2008) Institutional mechanisms for incorporating the public. In A. Freiberg \& K Gelb. (Eds) (2008) Penal Populism, Sentencing Councils and Sentencing Policy. Annandale, NSW: Hawkins Press.

Hutton, N. (2005) Beyond Populist Punitiveness?. Punishment \& Society, 7, 243258.

Kazin, M. (1998) The Populist Persuasion - An American History. Ithaca: Cornell University Press.

Koziol, M. (2013) Solidarity forever: as fare the unions, so goes the ALP. Politifact Australia, 30 September 2013 accessed at http://www.politifact.com.au/truth-ometer/article/2013/sep/30/fare-unions-so-goes-alp/

Lacey, N. (2008) The Prisoners' Dilemma: Political Economy and Punishment in Contemporary Democracies. New York: Cambridge University Press. 
Laclau, E. (2007) On Populist Reason. London: Verso.

Loader, I. \& Sparks, R. (2011) Public Criminology?. London: Routledge.

Loader, I. (2006) Fall of the 'Platonic Guardians': Liberalism, Criminology and Politics Responses to Crime in England and Wales. British Journal of Criminology, 46, 561586.

Loughnan, A. (2009) The Legislation we had to have? The Crimes (Criminal Organisations Control) Act (NSW). Current Issues in Criminal Justice, 20, 457-65.

Matthews, R. (2005) The Myth of Punitiveness. Theoretical Criminology, 9(2), 175201.

Mcllveen L (2012) Real Heroes Walk Away: Join the Fight against Violence (26 July 2012) news.com.au http://www.news.com.au/features/heroes-walk-away/heroeswalkaway-choose-how-your-night-ends/story-fneygm3n-1226434774642

Newburn, T. (2007) 'Tough on Crime': Penal Policy in England and Wales. Crime and Justice, 36, 425-470

NSW Bureau of Crime Statistics \& Research. (2013) New South Wales Recorded Crime Statistics: Quarterly Update March 2013.

New South Wales Government (2012) NSW Government Response to Issues in Kings Cross http://www.nsw.gov.au/sites/default/files/uploads/common/GovernmentResponse-Kings-Cross-Issues.pdf>

Payne, J. \& Gaffney, A. (2012) How much crime is drug or alcohol related? Selfreported attributions of police detainees. Trends \& issues in crime and criminal justice, No 439.

Pilgrim, J., Gerostamoulos, D., \& Drummer, O. (2013) "King hit" fatalities in Australia, 2000-2012: The role of alcohol and other drugs. Drug and Alcohol Dependence, Accepted publication at http://ac.els-

cdn.com/S0376871613004985/dx.doi.org/10.1016/j.drugalcdep.2013.11.019

Pratt, P. (2007) Penal Populism. London, Routledge.

Pratt, P. (2008) Penal Scandal in New Zealand. In A. Freiberg \& K Gelb. (Eds) (2008) Penal Populism, Sentencing Councils and Sentencing Policy. Annandale, NSW: Hawkins Press.

Pratt, P., \& Eriksson, A. (2013) Contrasts in Punishment: An explanation of Anglophone excess and Nordic exceptionalism. London: Routledge.

Queensland Government, Department of Premier \& Cabinet, (2013) Drink Safe Precincts: Evaluation update: 18 months of the trial. May 2013 
Quilter, J. (2013) Responses to the death of Thomas Kelly: Taking Populism Seriously. Current Issues in Criminal Justice, 24(3), pp. 439-48.

Quilter, J. (2014) The Thomas Kelly Case: Why a 'One Punch' Law is not the Answer' Criminal Law Journal (forthcoming)

Roberts, J., Stalans, L., Indermaur, D. \& Hough, M. (2003) Penal Populism and Public Opinion - Lessons from Five Countries. Oxford: Oxford University Press.

Roberts, J. \& Hough, M. (2002) Changing Attitudes to Punishment: Public opinion, crime and justice. Willan Publishing

Roberts, J. (2008) Sentencing Policy and Practice: the evolving role of public opinion. In A. Freiberg \& K Gelb. (Eds) (2008) Penal Populism, Sentencing Councils and Sentencing Policy. Annandale, NSW: Hawkins Press.

Shakeshift, A., Love, S. \& Wood, E. (2011) Alcohol-Related Crime in City of Sydney Local Government Area. National Drug \& Alcohol Research Centre, UNSW Monograph No 63.

Snowball, L. \& Spratley, S. (2013) Is the decrease in assaults at licensed premises being driven by changes in staff reporting rates?. Crime and Justice Statistics, No 87

Stoker, G. (2006) Why Politics Matters: Making Democracy Work. London: Palgrave.

Taggart, P. (2000) Populism. Buckingham: Open University Press.

UrbisJHD, (2006) Kings Cross Licensed Premises Research Prepared for City of Sydney 